\title{
Efficiency of small constructed wetlands for subsurface treatment of single-family domestic effluent
}

\author{
David Steer ${ }^{\mathrm{a}, *}$, Lauchlan Fraser ${ }^{\mathrm{b}}$, James Boddy ${ }^{\mathrm{c}}$, Beth Seibert ${ }^{\mathrm{d}}$ \\ a Geology Department, The University of Akron, Akron, OH 44325-4101, USA \\ b Biology Department, The University of Akron, Akron, OH 44325-3908, USA \\ ${ }^{\mathrm{c}}$ Lorain County Department of Health, 9880 S. Murray Ridge Road, Elyria, OH 44035, USA \\ d Ottawa River Coalition, 3900 Campus Dr., Suite A, Lima, OH 45804-3596 USA
}

Received 23 July 2001; received in revised form 26 November 2001; accepted 1 December 2001

\begin{abstract}
Single-family constructed wetland systems in Ohio, USA, are studied to evaluate their effectiveness in improving water quality. Twenty-one, three-cell systems (septic tank with two wetlands) are found to meet US Environmental Protection Agency (EPA) effluent load guidelines in 68\% of the quarterly water quality samples collected from 1994 to 2001. These wetlands most frequently meet EPA standards for mitigation of biochemical oxygen demand $(89 \%$ below $30 \mathrm{mg} / \mathrm{l})$; total suspended solids ( $79 \%$ below $30 \mathrm{mg} / 1)$; and fecal coliform ( $74 \%$ below 1000 counts $/ 100 \mathrm{ml})$. Phosphorus and ammonia discharge meet the guidelines less often $(50 \%$ at $1 \mathrm{mg} / 1$ and $16 \%$ at $1.5 \mathrm{mg} / 1$, respectively). These data also indicate that domestic treatment wetlands can reduce output of fecal coliform $88 \pm 27 \%$, total suspended solids $56 \pm 53 \%$, biochemical oxygen demand $70 \pm 48 \%$, ammonia $56 \pm 31 \%$ and phosphorus $80 \pm 20 \%$. Analysis of variance for these systems indicates that biochemical oxygen demand reduction is $\sim 10 \%$ less efficiently reduced during winter and ammonia was reduced $\sim 20 \%$ more efficiently in fall when compared with the other seasons. Phosphorus reductions display complex seasonal variations that imply that the least efficient phosphorus reduction occurs in winter and the most efficient reduction occurs in fall. (C) 2002 Elsevier Science B.V. All rights reserved.
\end{abstract}

Keywords: Wetlands; Wastewater; Pollution treatment; Domestic wastewater; Seasonality; Load reduction

\section{Introduction}

Recent surveys conducted by the USEPA indicate that failing septic systems are the third most frequently cited source of groundwater contamination in the United States (USEPA, 1998). Do-

\footnotetext{
* Corresponding author. Tel.: + 1-330-972-2099; fax: + 1330-972-7611.

E-mail address: steer@uakron.edu (D. Steer).
}

mestic septic systems are generally designed with pre-treatment in a septic tank that releases wastewater into constructed leaching areas. Pathogens in the wastewater degrade over time or are mitigated in the soil by naturally occurring biological organisms (Kadlec and Knight, 1996). Malfunction may occur when the systems are poorly constructed or not properly maintained, when soils are unsuitable, or from overuse. Releases to groundwater from household systems 
can include bacteria, nitrates, viruses and phosphorus. Such contaminates are of particular concern in rural areas, where domestic septic systems are prevalent and $95 \%$ of the population receives their fresh water from groundwater-recharged wells (Steiner and Combs, 1993; USEPA, 1998).

Constructed wetlands are increasingly used for the treatment of wastewater effluent because they are known to effectively treat pollution (Wood, 1995; Nokes et al., 1999; Mitsch and Gosselink, 2000). These systems effectively reduce total suspended solids, biochemical oxygen demand (Watson et al., 1990; Bhamidimarri et al., 1991) and fecal coliform (Nokes et al., 1999; Neralla et al., 2000). Nitrogen (ammonia and total nitrogen) and phosphorus are also mitigated but with widely varying efficiencies compared with other pathogens (Nichols, 1983; Mann, 1990; UrbancBercic and Bulc, 1995; Koottatep and Polprasert, 1997; Cronk and Fennessy, 2001). Seasonal changes in load reduction efficiency appear to be minimal (Maehlum et al., 1995; Wittgren and Maehlum, 1997).

In the late 1980s, the United States Environmental Protection Agency (USEPA) agreed that constructed wetlands were an appropriate management practice for treatment of domestic wastewater (Bastian et al., 1987). Financial incentives provided by local governments and typically lower operational costs for homeowners resulted in promulgation of these natural treatment systems across the United States. It is not known how many of these systems are currently in operation due to the vast scale and diversity of uses of treatment wetlands, but perhaps hundreds exist in the United States (Mitsch and Gosselink, 2000). Many of these constructed wetlands are not being actively monitored, thus making any data that can be reported of great value.

\section{Materials and methods}

The objective of this study is to understand wastewater treatment performance based on 21 domestic treatment wetlands in northern Ohio having identical flow design and in close geographic proximity. This study reports water qual- ity improvement results from 21 single-family domestic wastewater treatment wetlands constructed in five counties of northern Ohio (Fig. 1a). These systems serve from 1-7 family members and share a common three-stage design (Fig. 1b). The systems are located in regions where discharge to surface waters is required due to hydric soil conditions. Each system has a septic tank for primary treatment of the wastewater and 2 wetland treatment cells. Water from the septic tank enters the primary cell through a manually controlled water level control box. The treatment cells share a common design and are $4.5 \times 5.5 \mathrm{~m}$ wide, $0.46 \mathrm{~m}$ deep with a substrate of \# 8 riverbed gravel ( $\sim 3 \mathrm{~cm}$ diameter). Larger gravel is used at the inlets and outlets ( $\sim 6 \mathrm{~cm}$ diameter). The first cell is a minimum of $10 \mathrm{~cm}$ above the second cell to allow adequate gravity feed of the effluent to the second (polishing) wetland. Two of these systems have aeration units. One system included in the study is designed with longer, narrower cells $(12.9 \times 2.3 \mathrm{~m})$. All wetland cells are surrounded by earthen berms to prevent runoff from entering the wetlands. The first cell is lined with impermeable clay or a rubber liner to isolate it from the water table (site-specific requirement). The second cell is generally not intentionally sealed off as percolation and use of the soil column to reduce discharge from the site is deemed a positive element to the design. Cell 1 is generally planted with Scirpus (bulrushes) or Sagittaria (arrowhead). Cell 2 is generally planted with ornamental wetland plants (e.g. Acorus calamus, Lobelia carinalis, Asclepias incarnata and Pontederia cordata). Phragmites is an invader in some of the systems studied.

Sample collection at individual wetlands varied slightly, but in general a trained technician collected samples in accordance with an approved EPA or equivalent quality assurance project plan. Fecal coliform, biochemical oxygen demand $\left(\mathrm{BOD}_{5}\right)$, total suspended solids (TSS), ammonia $\left(\mathrm{NH}_{3}\right)$ and total phosphorus were measured based on quarterly visits to 21 treatment wetlands from September 1994 to January 2001. Quarterly monitoring involved sampling at the septic tank, at the inlet box between cell 2 and cell 3, and at the outlet box of cell 3. Effluent samples were col- 
lected sequentially at each site starting at the outlet and ending with the inlet (or septic tank). Samples were collected at the beginning of a week (Monday or Tuesday) to take advantage of maximum use of the systems that generally occurs on the weekend.

Sample collection procedures were standardized for quality assurance purposes. Fecal coliform samples were collected by using a sterile syringe to extract $\sim 100 \mathrm{ml}$ of fluid. The sample was then placed in a sterile polyethylene container. The container was immediately sealed, labeled and placed in an insulated cooler of ice. A clean siphon instrument was used to remove a $900 \mathrm{ml}$

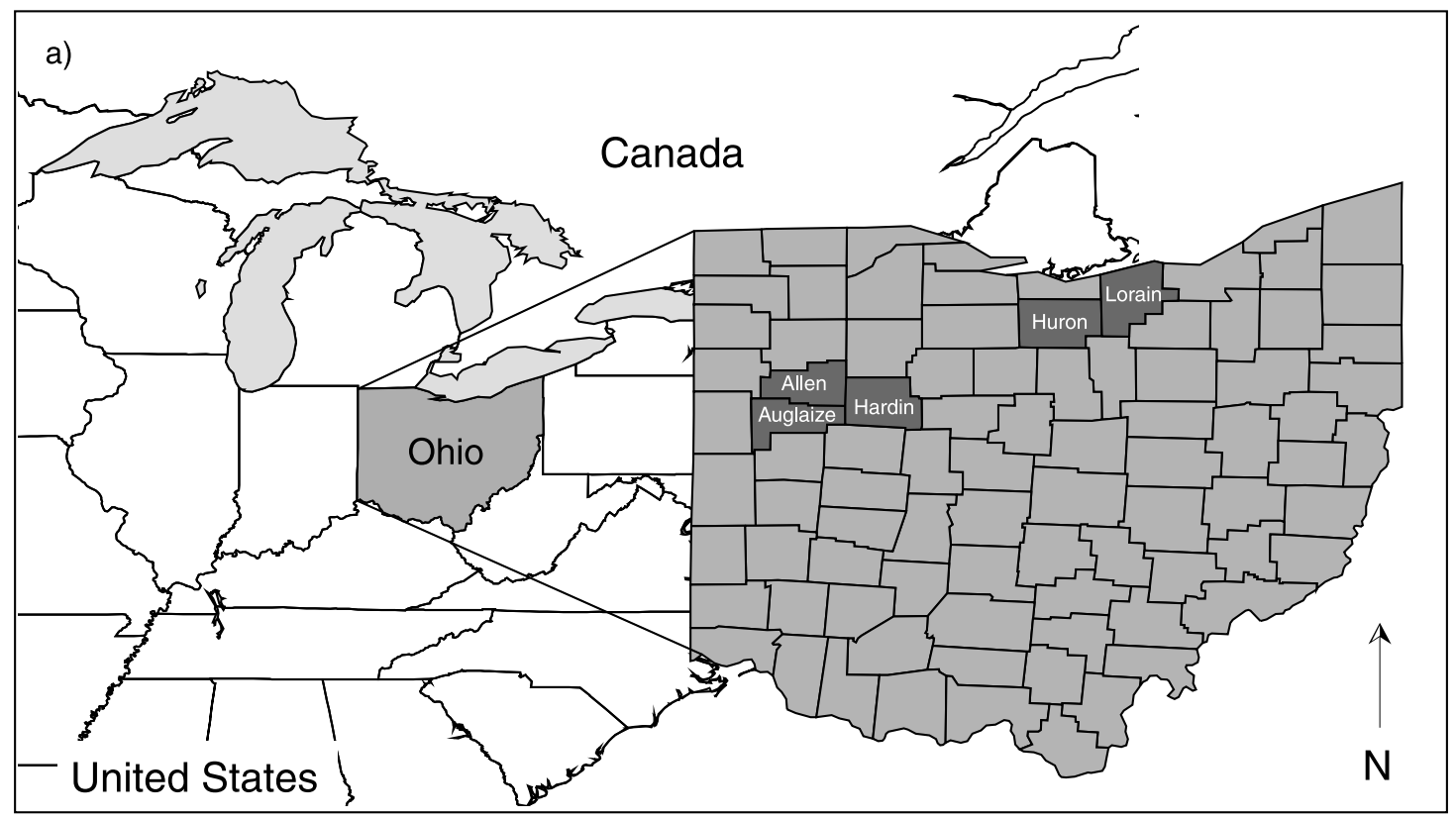

b)

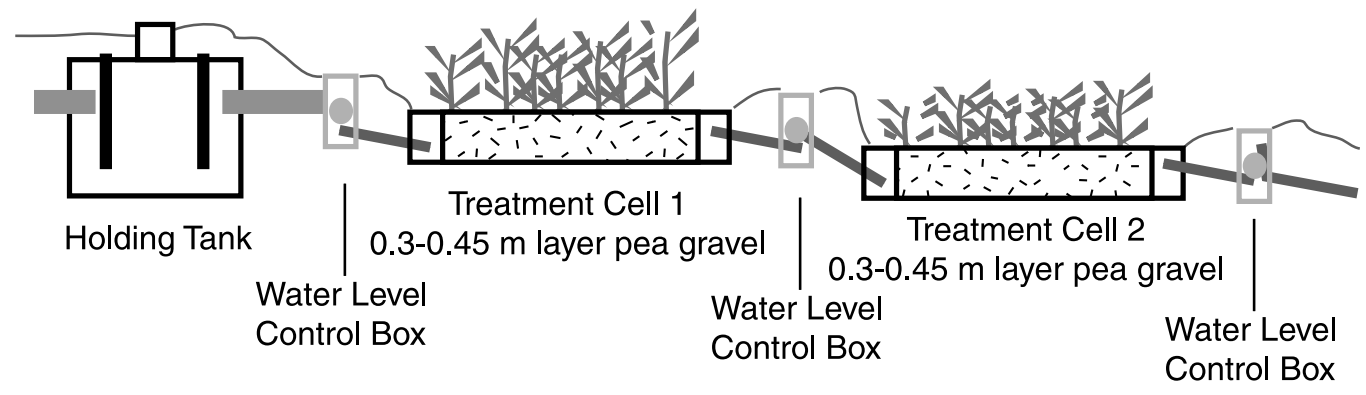

Fig. 1. (a) Regional location map with detailed image of counties with constructed wetlands where water quality data were available.

(b) Typical three-cell design of the single-family domestic wastewater treatment wetlands used in this study. 
Table 1

Analytical methods

\begin{tabular}{|c|c|c|c|c|c|}
\hline Parameter & Method & Reference & $\begin{array}{l}\text { Sample size container } \\
\text { plastic/glass }\end{array}$ & Preservation & Holding time \\
\hline $\begin{array}{l}\text { Biochemical } \\
\text { oxygen demand }\end{array}$ & 405.1 & USEPA, 1983 & $1000 \mathrm{ml} \mathrm{P} / \mathrm{G}$ & Cool, $4{ }^{\circ} \mathrm{C}$ & $48 \mathrm{~h}$ \\
\hline $\begin{array}{l}\text { Total suspended } \\
\text { solids }\end{array}$ & 160.2 & USEPA, 1983 & $500 \mathrm{ml} \mathrm{P} / \mathrm{G}$ & Cool, $4{ }^{\circ} \mathrm{C}$ & 7 days \\
\hline \multirow[t]{2}{*}{ Fecal coliform } & $9222 \mathrm{D}$ & $\begin{array}{l}\text { APHA-AWWA- } \\
\text { WPCF, } 1992\end{array}$ & $150 \mathrm{ml} \mathrm{P}$ sterile & Cool, $4{ }^{\circ} \mathrm{C}$ & $6 \mathrm{~h}$ \\
\hline & $9221 \mathrm{C}$ & & 503 Regs, MPN & $\mathrm{Na}_{2} \mathrm{~S}_{2} \mathrm{O}_{3}$ & $24 \mathrm{~h}$ \\
\hline Phosphorus & 365.3 & USEPA, 1983 & $50 \mathrm{ml} \mathrm{P} / \mathrm{G}$ & $\begin{array}{l}\mathrm{Cool}, 4{ }^{\circ} \mathrm{C} \mathrm{H}_{2} \mathrm{SO}_{4} \\
\text { to } \mathrm{pH}<2\end{array}$ & 28 days \\
\hline Ammonia & 350.3 & USEPA, 1983 & $400 \mathrm{ml} \mathrm{P} / \mathrm{G}$ & $\begin{array}{l}\mathrm{Cool}, 4{ }^{\circ} \mathrm{C} \mathrm{H}_{2} \mathrm{SO}_{4} \\
\text { to } \mathrm{pH}<2\end{array}$ & 28 days \\
\hline
\end{tabular}

TSS and BOD sample that was stored in a polyethylene bottle. Temperature and $\mathrm{pH}$ were measured in the field from this bottle. The bottle was then sealed and placed in an insulated cooler of ice until submitted to the laboratory for analysis. The last sample collected at each site was analyzed for ammonia and total phosphorus. A clean siphon instrument was used to remove an $\sim 900 \mathrm{ml}$ sample that was stored in a polyethylene bottle. The bottle was sealed and placed in an insulated cooler of ice until submitted to the laboratory for analysis. Technicians noted the date, time of sampling and air temperature. In cases, a qualitative assessment of percent plant cover by cell and flow conditions were also documented. Containers were delivered within $4 \mathrm{~h}$ of sampling to the EPA-approved laboratories for chemical analysis. Standard analytical methods were used to process the samples (Table 1).

\section{Results}

\subsection{Data}

Average input and output readings for individual systems (Table 2a-c) and from a combined database (Table 3) varied by as much as four orders of magnitude. Individual systems were analyzed to discover trends common across sampling data for individual wetlands. Data from all wetlands were combined to a single database to eval- uate overall performance trends representative of this particular two wetland-cell design. The combined database used for this study contained 644 coupled (input-output) raw data points for five loads monitored during 133 quarterly sample dates. The full 665-sample database was filtered to remove obviously erroneous values that resulted from no- or low-output systems and where samples were lost due to lab mishandling (12 samples). Nine data points having an occurrence probability less than 0.004 were rejected using Chauvenet's criteria. The large variances in loads and outputs result in standard deviations of the means sometimes larger than the means themselves (Table 2a-c Table 3). Data (input and output counts and/or concentrations) were converted to percent reductions in load ( 1 - output/ input expressed as a percentage) to minimize the influence of large loads on the analyses. This method of data reduction also allows direct comparisons of load reduction efficiency with input and output loads and seasons. Mass removals were not used since actual flow information was not recorded for these wetlands.

All data from the individual wetlands are combined to a single database since samples were collected in all months of the calendar year except May. The data were grouped to seasonal quarters for temporal analyses and later sorted based on EPA effluent guidelines. When combined, the wetlands were sampled a total of 27 times during the first quarter (December, January and February), 
Table 2

System performance

\begin{tabular}{|c|c|c|c|c|c|c|c|}
\hline System & $\begin{array}{l}\text { People } \\
\text { served }\end{array}$ & $\begin{array}{l}\text { Fecal in counts } / 100 \\
\mathrm{ml}\end{array}$ & $\begin{array}{l}\text { Fecal out } \\
\text { counts } / 100 \mathrm{ml}\end{array}$ & $\begin{array}{l}\text { Fecal } \% \\
\text { reduced }\end{array}$ & $\begin{array}{l}\text { TSS in } \\
(\mathrm{mg} / \mathrm{l})\end{array}$ & $\begin{array}{l}\text { TSS out } \\
(\mathrm{mg} / \mathrm{l})\end{array}$ & $\begin{array}{l}\text { TSS } \\
\% \text { reduced }\end{array}$ \\
\hline $1^{\mathrm{a}}$ & 6 & $730 \pm 1120$ & $50 \pm 40$ & 93.2 & $28 \pm 30$ & $21 \pm 14$ & 25.0 \\
\hline $2^{\mathrm{b}}$ & 6 & $75460 \pm 76650$ & $1370 \pm 1410$ & 98.2 & $48 \pm 15$ & $18 \pm 13$ & 62.5 \\
\hline 3 & 2 & $11120 \pm 16600$ & $40 \pm 50$ & 99.6 & $45 \pm 51$ & $23 \pm 27$ & 48.9 \\
\hline 4 & 4 & $11420 \pm 18210$ & $910 \pm 1370$ & 92.0 & $60 \pm 15$ & $37 \pm 14$ & 38.3 \\
\hline 5 & 5 & $65500 \pm 77910$ & $1560 \pm 1540$ & 97.6 & $35 \pm 7$ & $12 \pm 5$ & 65.7 \\
\hline 6 & 5 & $78480 \pm 77520$ & $10280 \pm 18100$ & 86.9 & $73 \pm 39$ & $21 \pm 8$ & 71.2 \\
\hline 7 & 1 & $1930 \pm 3450$ & $180 \pm 406$ & 90.7 & $64 \pm 64$ & $7 \pm 4$ & 89.1 \\
\hline 8 & 1 & $27850 \pm 31390$ & $190 \pm 350$ & 99.3 & $64 \pm 47$ & $15 \pm 10$ & 76.6 \\
\hline $9^{a}$ & 4 & $48520 \pm 85620$ & $100 \pm 100$ & 99.8 & $87 \pm 29$ & $17 \pm 11$ & 80.5 \\
\hline 10 & 4 & $88460 \pm 102200$ & $110 \pm 160$ & 99.9 & $55 \pm 18$ & $20 \pm 12$ & 63.6 \\
\hline 11 & 2 & $118350 \pm 194600$ & $107 \pm 155$ & 99.9 & $53 \pm 9$ & $10 \pm 7$ & 81.1 \\
\hline 12 & 2 & $38070 \pm 32960$ & $1360 \pm 1760$ & 96.4 & $66 \pm 20$ & $28 \pm 17$ & 57.6 \\
\hline 13 & 2 & $16600 \pm 6450$ & $660 \pm 770$ & 96.0 & $22 \pm 9$ & $5 \pm 1$ & 77.3 \\
\hline 14 & 1 & $19710 \pm 760$ & $540 \pm 930$ & 97.3 & $22 \pm 12$ & $16 \pm 3$ & 27.3 \\
\hline 15 & 5 & $20000 \pm 0$ & $1190 \pm 2610$ & 94.1 & $33 \pm 14$ & $6 \pm 3$ & 81.8 \\
\hline 16 & 6 & $17180 \pm 7470$ & $1235 \pm 1920$ & 92.8 & $35 \pm 16$ & $14 \pm 12$ & 60.0 \\
\hline 17 & 2 & $20000 \pm 0^{\mathrm{c}}$ & $270 \pm 390$ & 98.7 & $26 \pm 10$ & $91 \pm 30$ & -250.0 \\
\hline 18 & 6 & $20000 \pm 0^{\mathrm{c}}$ & $14420 \pm 7110$ & 27.9 & $163 \pm 248$ & $28 \pm 29$ & 82.8 \\
\hline 19 & 7 & $20000 \pm 0^{\mathrm{c}}$ & $10680 \pm 10770$ & 82.7 & $41 \pm 18$ & $28 \pm 35$ & 31.7 \\
\hline 20 & 5 & $20000 \pm 0^{\mathrm{c}}$ & $3470 \pm 8100$ & 82.7 & $50 \pm 11$ & $22 \pm 15$ & 56.0 \\
\hline 21 & 3 & $20000 \pm 0^{\mathrm{c}}$ & $200 \pm 210$ & 99.0 & $27 \pm 2$ & $20 \pm 15$ & 25.9 \\
\hline
\end{tabular}

(b) System

$\mathrm{BOD}_{5}$ in $(\mathrm{mg} / 1)$
$\mathrm{BOD}_{5}$ out $(\mathrm{mg} / \mathrm{l})$
$\mathrm{BOD}_{5} \%$ reduced
$\mathrm{NH}_{3}$ in (mg/l)
$\mathrm{NH}_{3}$ out (mg/l)
$\mathrm{NH}_{3} \%$ reduced

\begin{tabular}{lcccccc}
\hline $1^{\mathrm{a}}$ & $10.3 \pm 13.7$ & $7.5 \pm 3.3$ & 27.2 & $8.1 \pm 8.0$ & $6.5 \pm 5.0$ & 19.8 \\
$2^{\mathrm{b}}$ & $80.2 \pm 41.7$ & $6.6 \pm 4.5$ & 91.8 & $32.2 \pm 10.0$ & $12.6 \pm 9.1$ & 61.0 \\
3 & $38.5 \pm 46.5$ & $3.7 \pm 4.7$ & 90.4 & $48.6 \pm 16.4$ & $4.5 \pm 5.7$ & 98.4 \\
4 & $95.2 \pm 55.6$ & $13.3 \pm 10.5$ & 86.0 & $39.4 \pm 7.8$ & $26.4 \pm 9.5$ & 33.0 \\
5 & $56.8 \pm 30.7$ & $9.6 \pm 4.0$ & 83.1 & $24.6 \pm 6.0$ & $10.4 \pm 11.0$ & 57.7 \\
6 & $100.6 \pm 40.2$ & $16.1 \pm 8.1$ & 84.0 & $40.2 \pm 1.6$ & $25.7 \pm 3.5$ & 36.1 \\
7 & $70.9 \pm 75.1$ & $2.9 \pm 1.8$ & 95.9 & $46.1 \pm 35.6$ & $1.5 \pm 1.4$ & 96.7 \\
8 & $66.9 \pm 51.1$ & $15.2 \pm 13.8$ & 77.3 & $97.8 \pm 45.0$ & $15.3 \pm 16.8$ & 84.4 \\
9 & $57.2 \pm 50.3$ & $9.4 \pm 6.3$ & 83.6 & $12.8 \pm 6.2$ & $7.3 \pm 4.4$ & 43.0 \\
10 & $139.6 \pm 63.2$ & $9.4 \pm 6.1$ & 93.3 & $37.6 \pm 5.6$ & $9.0 \pm 4.8$ & 76.1 \\
11 & $112.3 \pm 67.3$ & $5.8 \pm 4.5$ & 94.8 & $44.3 \pm 7.5$ & $3.5 \pm 3.0$ & 92.1 \\
12 & $160.6 \pm 75.0$ & $10.5 \pm 6.3$ & 93.5 & $78.3 \pm 19.6$ & $42.0 \pm 15.1$ & 46.4 \\
13 & $118.3 \pm 65.9$ & $32.6 \pm 44.4$ & 72.4 & $25.9 \pm 10.9$ & $12.7 \pm 2.7$ & 51.0 \\
14 & $160.2 \pm 86.3$ & $8.4 \pm 3.3$ & 94.8 & $33.7 \pm 9.0$ & $6.7 \pm 7.3$ & 80.1 \\
15 & $148.9 \pm 57.1$ & $15.1 \pm 12.6$ & 89.9 & $34.7 \pm 9.7$ & $13.1 \pm 8.0$ & 62.2 \\
16 & $150.5 \pm 105.6$ & $43.7 \pm 37.1$ & 70.9 & $34.3 \pm 11.2$ & $21.3 \pm 8.3$ & 37.7 \\
17 & $71.0 \pm 51.5$ & $14.9 \pm 0.2$ & 79.0 & $6.8 \pm 1.8$ & $3.4 \pm 0.6$ & 50.0 \\
18 & $193.3 \pm 84.5$ & $48.6 \pm 37.6$ & 74.9 & $51.1 \pm 12.1$ & $37.5 \pm 11.2$ & 26.6 \\
19 & $161.0 \pm 81.1$ & $21.6 \pm 14.7$ & 86.6 & $36.9 \pm 20.0$ & $16.2 \pm 4.8$ & 56.1 \\
20 & $135.9 \pm 81.7$ & $16.7 \pm 19.1$ & 87.7 & $116.8 \pm 58.0$ & $46.2 \pm 23.3$ & 60.4 \\
21 & $111.9 \pm 98.4$ & $29.2 \pm 23.4$ & 73.9 & $43.4 \pm 15.8$ & $16.1 \pm 7.2$ & 62.9
\end{tabular}


Table 2 (Continued)

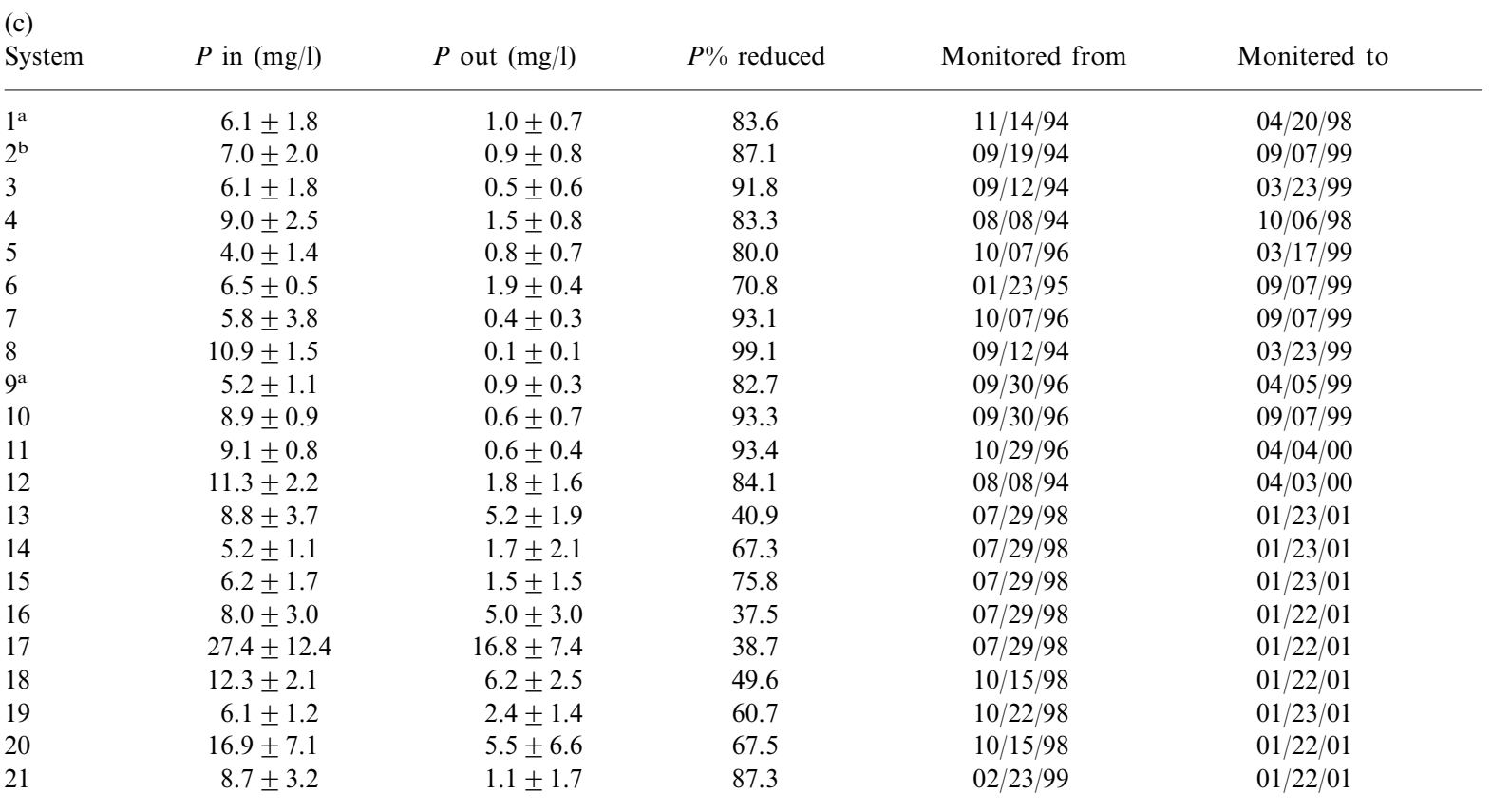

a Aeration unit.

${ }^{\mathrm{b}}$ Cell dimensions $12.5 \times 2.3 \times 0.46 \mathrm{~m}$.

c Minimum count.

37 times during the second quarter (March-May), 11 times in summer (June-August) and 57 times in fall (September-November). Seasons are not equally sampled because the wetlands were established on different dates, all wetlands were not monitored for the entire 6-year period, and some quarters were simply not monitored for logistical or budgetary reasons. Information regarding $\mathrm{pH}$, nitrate, $\mathrm{NO}_{3} / \mathrm{NO}_{2}$, and $\mathrm{DO}$ were excluded from this study since these parameters were not measured at all of the sites.

Analysis of variance (ANOVA) was used to test data for seasonal effects in water quality improvement. Paired, one-tail $T$-tests were used to confirm trends when appropriate based on ANOVA. $T$ tests were also used to analyze the relationships between input, output and treatment efficiency of systems that meet EPA effluent guidelines compared with those that do not. Output data are compared with EPA effluent standards for munic- ipal wastewater (EPA, 1999) since no firm standards are established for domestic systems.

\subsection{Fecal coliform}

These wetlands individually reduce fecal coliform from 82.7 to $99.9 \%$ (Table 2a) with one exception (ID 18 at 27.9\%). Three of the systems (Table 2a; IDs 6, 18 and 19) display output loads at least one order of magnitude larger than the other 18 systems yet have no obvious difference in input load. Overall, fecal coliform is reduced $87.9 \pm 27.1 \%$ from input to output in these wetlands (Table 3). Effluent is discharged from the polishing cell of these wetlands at levels below the EPA recommended 1000 counts $/ 100 \mathrm{ml}$ in $74 \%$ of samples (98 of 132). Two of the systems (Table 2a; ID 18 and 19) fail to meet these standards on every test. Nine wetlands (Table 2a; IDs 1, 3, 7, 8, 9, 10, $11,17,21)$ met the standard on every occasion. 


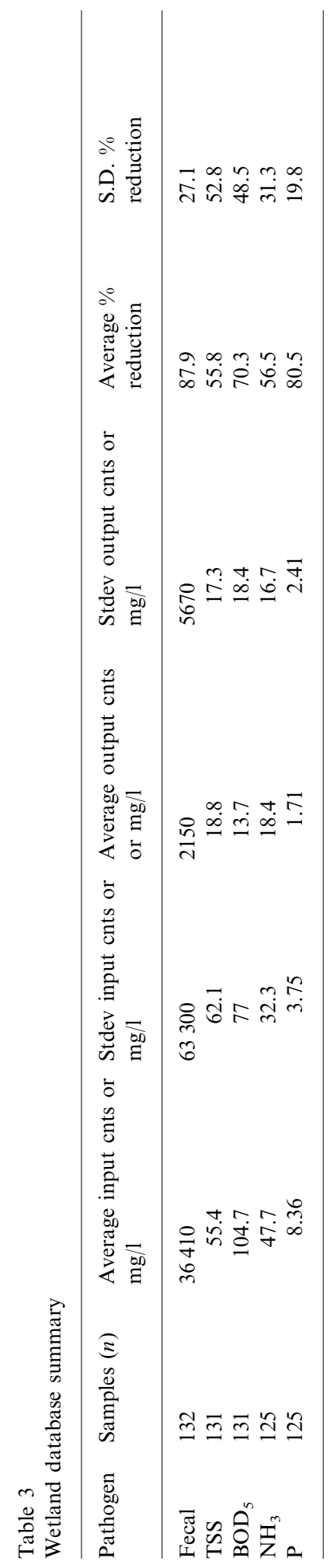


When data are organized into pass/fail bins based on the EPA criterion, $T$-tests indicate that the failing systems have twice the input load of the passing systems (26000 colonies/100 ml compared with 50000; $P<0.01)$. Systems that do not meet guidelines are $\sim 15 \%$ less efficient at reducing loads than those meeting the standard $(P<0.01)$. Poorly functioning systems output effluent with coliform levels $\sim 7$ times higher than the EPA guideline while functioning systems output this pathogen at $\sim 17 \%$ of the limit $(P<0.001)$. The data were not suitable for analyses of seasonal effects on fecal coliform reduction efficiency.

\subsection{Total suspended solids (TSS)}

These wetlands individually reduce TSS with efficiencies ranging from 25.0 to $89.1 \%$ (Table 2a) with one exception (ID 17 at $-250.0 \%$ ). In general, TSS is reduced by $55.8 \pm 52.8 \%$ using the subsurface treatment wetland process (Table 3). Suspended solids are released at levels below the EPA recommended $30 \mathrm{mg} / 1$ in $79 \%$ of the samples (104 of 131). Two systems (Table 2a; IDs 4 and 12) fail to meet standards in most samples. Five systems (Table 2a; IDs 5, 7, 11, $13,15)$ met the standard on every sample date. Statistical analyses indicate that failed samples are from wetlands that have an $\sim 33 \%$ higher input load than those from passing systems $(P<0.04)$. Likewise, reduction efficiencies are $\sim 50 \%$ lower than comparable systems that meet the guidelines ( 72 vs. $34 \% ; P<0.0005$ ). Systems that fail to meet the EPA threshold output have more than three times the solids of systems that pass the standard (42 vs. $13 \mathrm{mg} / \mathrm{l} ; P<0.0005$ ). Measurements of TSS are inconclusive concerning seasonal effects in wetland effectiveness.

\subsection{Biochemical oxygen demand $\left(B O D_{5}\right)$}

These wetlands individually reduce $\mathrm{BOD}_{5}$ from 70.9 to $95.9 \%$ (Table 2 b) with one exception (ID 1 at 27.2\%). Overall these treatment wetlands reduce $\mathrm{BOD}_{5} 70.3 \pm 48.5 \%$ (Table 3) when monitoring data are combined. Biochemical activity as measured by $\mathrm{BOD}_{5}$ is less than the $30 \mathrm{mg} / 1 \mathrm{EPA}$ guideline in $89 \%$ of the sam- ples (107 of 131). Two wetlands (Table 2b; IDs 16 and 18) fail to meet the EPA standard in two-third of the samples. When samples indicate a wetland is not meeting the $30 \mathrm{mg} / 1$ limit, input loads appear to be double that of samples meeting the standard (200 vs. $100 \mathrm{mg} / 1 ; P<0.001)$. The output loads of faulty systems are $\sim 60$ $\mathrm{mg} / \mathrm{l}$ compared with $\sim 9 \mathrm{mg} / 1$ for systems meeting the standard $(P<0.001)$. Overall treatment efficiencies vary by $\sim 15 \%(P<0.01)$. Seasonal changes in biologic activity appear to be present in these data (standard deviation ratio $=2.2$; $F=3.6 ; P=0.02$ ). Paired one-tailed $T$-tests indicate that mean $\mathrm{BOD}_{5}$ reduction is $\sim 10 \%$ less efficient in winter compared with spring, summer and fall $(P<0.01$ that means are the same). There appears to be no difference in the mean reduction of $\mathrm{BOD}_{5}$ when comparing data between the other seasons.

\subsection{Ammonia}

Ammonia is the least efficiently treated pathogen in these wetlands as it is reduced only $19.8-$ $98.4 \%$ at individual wetlands (Table 2b) and $56.5 \pm 31.3 \%$ in general from input to output (Table 3). System ID 1 (Table 2b) is the least ammonia reducing system and also has the lowest input loads. In general, only $16 \%$ of the samples (18 out of 125) in this study meet the $1.5 \mathrm{mg} / 1 \mathrm{EPA}$ effluent guideline. All wetlands fail to meet the criterion on one or more sample dates. There are no significant statistical differences between input loads of systems that meet the standard compared with those that do not. Output loads for systems meeting the standard are $\sim 0.7$ compared with $21.7 \mathrm{mg} / 1$ in those instances where the standard is exceeded $(P<$ 0.0005). In the small number of cases where EPA guidelines are met, treatment efficiency is $\sim 97 \%$ compared with $\sim 53 \%$ for failing systems $(P<0.001)$. Ammonia data appear to show seasonality (standard deviation ratio $=1.5$; $F=6.4 ; \quad P=0.00005)$. Paired one-tailed $T$-tests indicate that mean ammonia reduction is $\sim 20 \%$ less efficient in winter, spring and summer compared with fall $(P<0.005$ that means are the same). Paired $T$-test analyses for all 
months with adequate data (January-April, June, September-November) further indicate that ammonia is more efficiently processed in September and October compared with all other months (with the exception of February and March for October data). There appears to be no difference in mean reduction of ammonia when comparing data between the other seasons.

\subsection{Phosphorus}

These wetlands are individually capable of capturing $37.5-99.1 \%$ of the total phosphorus entering the wetlands. Three of the systems (Table 2c; IDs 16,17 and 18) reduce less than $50 \%$ of the phosphorous present in the input wastewater. Overall, phosphorus in domestic wastewater is reduced by $80.5 \pm 19.8 \%$ in these wetlands (Table $3)$. EPA recommended guidelines $(1.0 \mathrm{mg} / \mathrm{l})$ are exceeded in $\sim 50 \%$ of the outlet samples. One system (Table 2c; ID 16) fails to meet standards on all occasions and two systems (Table 2c; IDs 7 and 8) always meet the standard. Wetland input concentrations in systems meeting the standard are $7.7 \mathrm{mg} / 1$ compared with $9.0 \mathrm{mg} / 1$ in wetlands that are not meeting the standard $(P<0.025)$. When the EPA guideline is met, output concentrations of phosphorus are $0.36 \mathrm{mg} / 1$ compared with $3.1 \mathrm{mg} / 1(P<0.001)$. If the EPA criterion is met, reduction efficiency is high at $94 \%$ compared with $65 \%$ efficiency when it is not met $(P<0.001)$. Phosphorus data appear to indicate seasonality (standard deviation ratio $=2.1 ; \quad F=5.8 ; \quad P=$ $0.001)$. Phosphorus is reduced $\sim 10 \%$ less efficiently when comparing winter to spring and summer and $\sim 20 \%$ less efficiently compared with fall $(P<0.005 ; 0.05 ; 0.001$ respectively). There is no apparent difference in mean $P$ reduction from spring to summer, but efficiency is $\sim 10 \%$ better in fall compared with spring and summer $(P<$ 0.001 and 0.025 , respectively).

\section{Discussion}

\subsection{Fecal coliform}

With the exception of system 18, these wetlands treat fecal coliform with efficiencies commensurate with results reported for similar systems with different designs (Bhamidimarri et al., 1991; Maehlum et al., 1995; Neralla et al., 2000). Detailed analyses of the data and observer notes for system 18 may imply that cell 2 is responsible for the failure of this system. From input to output, this wetland initially appeared to reduce fecal counts albeit with degraded performance in sequential samplings (October 1998, 20000+ to 3500; February 1999, $20000+$ to 8100 ; and April 1999, $20000+$ to 14900). After April 1999, the system completely failed with input and output counts were both over 20000 colonies. In June 1999, the system had flow through control box 2 from the second cell. However, there was no flow through control box 2 of system 18 for all subsequent measurements despite having continuous flow from the outlet of cell 3 .

Several factors may have contributed to the failure of this individual system in treating fecal coliform. System 18 was established in August 1998, but not planted until spring 1999. The delay in planting may have been a factor. However, any impact on system performance due to the delay in planting is considered minimal. Four other systems (Table 2a; IDs 16, 19, 20 and 21) had similar establishment and planting schedules and did not fail. In general, fecal coliform are reduced in wastewater by decreased temperatures, ultraviolet radiation or predation from protozoa (USEPA, 1999). Since there was no flow through control box 2 , flow to cell 3 could only occur if cell 2 was bypassed through either lateral flow around or channel flow through cell 2. The presumed disrupted flow could occur as a result of breaches to the clay liners, full blockage of transfer pipes or partial or full obstruction in the substrate. A change in flow might also change the retention time of the wastewater, thus minimizing the time available for protozoa to consume the fecal coliform.

\section{2. $T S S$}

Except for location 17, average TSS reductions of $55.8 \pm 52.8 \%$ closely agree with studies conducted elsewhere (Kentucky; Watson et al., 1990). 
TSS data from traditional systems (Kadlec and Knight, 1996) and comparable wetlands in Texas (Neralla et al., 2000) and France (Lienard et al., 1990) display higher efficiencies than those found here $(80,88$ and $85 \%$, respectively), but fall within the confidence interval of these data. The large negative efficiency at location 17 is dominated by two samples that display very large remobilizations $(-102 \%$ in April of 1999 and $-1233 \%$ in June 1999). These large outputs are considered anomalous as readings before and after these samples display overall reductions in TSS. There were no observations in field notes to indicate why solids were remobilized during these sampling periods. TSS consists of solid feces, bacteria and sediment that are filtered from the wastewater in the wetland by incorporation into the substrate. Remobilization of the solids are known to occur and can limit the overall effectiveness and longevity of the wetland treatment systems (Kadlec, 1995).

\section{3. $\mathrm{BOD}_{5}$}

Individual system $\mathrm{BOD}_{5}$ reduction efficiencies for systems 2-21 (Table 2b) and overall average efficiencies of $70.3 \pm 40.5 \%$ are similar to those reported for wetlands in other regions (Bhamidimarri et al., 1991; Maehlum et al., 1995; Neralla et al., 2000). BOD is directly related to microbial activity resulting in a reduction in available oxygen in the wastewater. BOD is reduced when dissolved oxygen is replaced through respiration, fermentation, and reduction of nitrates (Kadlec, 1995). The low reduction efficiency for system 1 is attributed to an aeration unit that dramatically reduces input loads relative to output loads rather than by any design issue with the wetlands.

\subsection{Ammonia}

Ammonia is treated within limits commonly found in wetland treatment systems. The low ammonia removal efficiency of these systems individually and collectively is expected based on other treatment wetland studies (Gersberg et al.,
1983; Hammer and Knight, 1994; Koottatep and Polprasert, 1997). The upper limit of the ammonia reduction confidence interval for these data $(87 \%)$ falls within the $80-95 \%$ removal rate cited for conventional systems employing tertiary treatment (Kadlec and Knight, 1996). The lowest ammonia treatment efficiency is again associated with system ID 1 and is attributed to low input loads resulting from aeration prior to entry to cell 1 .

\subsection{Phosphorus}

Phosphorus reduction also falls within the 80-97\% range cited for other regions (Maehlum et al., 1995; Urbanc-Bercic and Bulc, 1995) and conventional treatment (Kadlec and Knight, 1996). Mann (1990) noted that the effectiveness of wetlands in treating $\mathrm{P}$ concentrations is a function of the adsorption capacity of the substrate. Variability in the $\mathrm{P}$ reduction efficiencies of these systems is not likely directly related to the substrate since these systems use the same material (with the exception of system 2). Input loads also do not vary appreciable from system to system (with the exception of system 17; Table 2c). Maintenance is a difficult to quantify the factor that may be related to $P$ reduction efficiency. Annual plant harvesting is necessary to remove nutrients that accumulate in the vegetation. These systems are not routinely harvested thus providing a source of $\mathrm{P}$ from decaying plant tissue (Brix, 1997).

\subsection{Seasonal effects}

Seasonal changes in biological activity play a minor role in the overall treatment efficiency of these subsurface wetlands. Average seasonal temperatures for the region where these wetlands are located are $-0.3 \pm 2.8^{\circ} \mathrm{C}$ (winter), $10.0 \pm 5.5^{\circ} \mathrm{C}$ (spring), $22.2 \pm 1.3{ }^{\circ} \mathrm{C}$ (summer) and $12.7 \pm$ $5.4{ }^{\circ} \mathrm{C}$ (fall). These systems display slight decreases $(10-20 \%)$ in $\mathrm{BOD}_{5}$ and $\mathrm{P}$ reduction efficiency in winter compared with the other seasons. Such reductions in efficiency are expected, 
as plants die and microbial action decreases during the winter season (Maehlum et al., 1995; Maehlum and Stalnacke, 1999). The $20 \%$ increase in ammonia treatment efficiency in the fall compared with all other seasons is problematic to explain. Several studies (Gersberg et al., 1986; Harberl and Perfler, 1991; Reed, 1993; Koottatep and Polprasert, 1997) show that biological activity plays a central role in ammonia removal in wetlands. The improved ammonia removal documented here occurs during a time of the year when biological activity and thus overall ammonia uptake should be decreasing. These data may indicate that the removal of ammonia in small domestic wetlands is influenced more by other factors such as $\mathrm{pH}$ and/or temperature than biologic activity.

\subsection{Implication for future designs}

EPA wastewater effluent standards for municipal constructed wetlands (EPA, 1999) are reasonable goals for domestic systems but will not likely be achieved for ammonia or phosphorus. These domestic wetlands behave with expected reduction efficiencies for fecal coliform, TSS and BOD. The relatively small loads present in these single-family systems are generally reduced below recommended levels. Though failures do occur, in many cases a failure is isolated to a single quarter that cannot be attributed to a particular season. Many times, failure of the same load is not repeated during the next sampling period. There appears to be no systematic reason in these data why a given wetland would fail one or more samples during one period, but pass on the next sampling period. Remedial action to correct recurring failures can only be accomplished through more systematic monitoring designed to more fully document failure trends. Ammonia and phosphorus standards will clearly not be met in these systems as they are currently designed. Since the reduction rates documented here are representative of this type of wetland, additional research should be undertaken to find better ways to reduce ammonia and phosphorus output.

\section{Conclusions}

Analysis of this database indicates that functional domestic treatment wetlands significantly reduce output loads and in cases can greatly improve water quality. Pathogen load reductions (output/input) are $88 \pm 27 \%$ for fecal coliform, $56 \pm 53 \%$ for TSS, $70 \pm 48 \%$ for $\mathrm{BOD}_{5}, 56 \pm$ $31 \%$ for $\mathrm{NH}_{3}$ and $80 \pm 20 \%$ for $P$ (Table 3 ). Individual loads were analyzed using analysis of variance and $T$-tests to search for seasonal influences. Seasonal influences on $\mathrm{BOD}_{5}$, phosphorus and ammonia are present in these wetlands. $\mathrm{BOD}_{5}$ reduction is $\sim 10 \%$ less in winter compared with spring, summer and fall and there appears to be no difference in mean reduction of $\mathrm{BOD}_{5}$ when comparing data between the other seasons. Phosphorus appears to be reduced less efficiently when comparing winter to spring, summer and fall. There is no apparent difference in mean $P$ reduction from spring to summer, but efficiency is $\sim 10 \%$ better in fall compared with spring and summer. Ammonia reduction is documented to be more efficient during a period of the year that suggests biologic activity is not the central factor in ammonia removal. These wetlands are found to be at or below recommended EPA effluent levels in $66 \%$ of the samples tested. $\mathrm{BOD}_{5}$ most frequently meets the standard ( $89 \%$ of the samples) and ammonia output most frequently fails to meet the guidelines (fails in $84 \%$ of samples). Additional monitoring and studies are required to determine the type of design changes required to reduce ammonia and phosphorus to acceptable levels.

\section{Acknowledgements}

The authors would like to thank all the technicians who collected these data over the duration of this project. They also acknowledge that funding to collect and process much of the water quality data was obtained through local governments and organizations. The authors also thank 
three anonymous reviewers for their comments that improved the final manuscript. This publication was financed in part through a grant from the Ohio Environmental Protection Agency and the United States Environmental Protection Agency, under the provisions of Section 319(h) of the Clean Water Act.

\section{References}

APHA-AWWA-WPCF, 1992. In: Greenberg, A.E., Clesceri, L.S., Eaton, A.D. (Eds.), Standard methods for examination of water and wastewater, 19th ed. American Public Health Association, Washington, DC.

Bastian, R.K., Shanaghan, P., Thompson, B., 1987. Report on the use of wetlands for municipal wastewater treatment and disposal (EPA 430/09-88-005). USEPA, Washington, DC.

Bhamidimarri, R., Shilton, A., Armstrong, I., Jacobson, P., Scarlet, D., 1991. Constructed wetlands for wastewater treatment: the New Zealand experience. Water Sci. Technol. 24 (5), 247-253.

Brix, H., 1997. Do macrophytes play a role in constructed treatment wetlands. Water Sci. Technol. 35 (5), 11-17.

Cronk, J.K., Fennessy, M.S., 2001. Wetland Plants: Biology and Ecology. Lewis Publishers, New York, pp. 462.

Gersberg, R.M., Elkins, B.V., Goldman, C.R., 1983. Nitrogen removal in artificial wetlands. Water Sci. Technol. 17 (9), 1009-1014.

Gersberg, R.M., Elkins, B.V., Lyon, S.R., Goldman, C.R., 1986. Role of aquatic plants in wastewater treatment by artificial wetlands. Water Res. 20 (3), 363-368.

Hammer, D.A., Knight, R.L., 1994. Designing constructed wetlands for nitrogen removal. Water Sci. Technol. 29 (4), $15-27$.

Harberl, R., Perfler, R., 1991. Nutrient removal in the reed bed system. Water Sci. Technol. 23 (4-6), 729-737.

Kadlec, R.H., 1995. Overview: surface flow constructed wetlands. Water Sci. Technol. 32 (3), 1-12.

Kadlec, R.H., Knight, R.L., 1996. Treatment Wetlands. Lewis Publishers, New York, pp. 893.

Koottatep, T., Polprasert, C., 1997. Role of plant uptake on nitrogen removal in constructed wetlands located in the tropics. Water Sci. Technol. 36 (12), 1-8.

Lienard, A., Boutin, C., Esser, D., 1990. Domestic wastewater treatment with emergent hydrophyte beds in France. In: Cooper, P.F., Findlater, B.C. (Eds.), Constructed Wetlands in Water Pollution: Advances in Water Pollution Control. Pergamon Press, Great Britain, pp. 183-192.

Maehlum, T., Stalnacke, P., 1999. Removal efficiency of three cold-climate constructed wetlands treating domestic wastewater: effects of temperature, seasons, loading rates and input concentrations. Water Sci. Technol. 40 (3), $273-281$.

Maehlum, T., Jenssen, P.D., Warner, W.S., 1995. Cold-climate constructed wetlands. Water Sci. Technol. 32 (3), 95-101.

Mann, R.A., 1990. Phosphorus removal by constructed wetlands: substratum adsorption. In: Cooper, P.F., Findlater, B.C. (Eds.), Constructed Wetlands in Water Pollution: Advances in Water Pollution Control. Pergamon Press, Great Britain, pp. 97-105.

Mitsch, W.J., Gosselink, J.G., 2000. Wetlands, 3rd ed. Wiley, New York, pp. 936.

Neralla, S., Weaver, R.W., Lesikar, B.J., Persyn, R.A., 2000. Improvement of domestic wastewater quality by subsurface flow constructed wetlands. Biores. Technol. 75, 19-25.

Nichols, D.S., 1983. Capacity of natural wetlands to remove nutrients from wastewater. J. Wat. Poll. Contr. Fed. 55, 495-505.

Nokes, R.L., Gerba, C.P., Karpiscak, M.M., 1999. Reduction of enteric organisms in small-scale, subsurface flow constructed wetlands. In: Means, J.L., Hinchee, R.E. (Eds.), Wetlands and Remediation: Wastewater Remediation and Treatment. Battelle Press, Columbus Ohio, pp. 195-203.

Reed, S.C., 1993. Subsurface flow constructed wetlands for wastewater treatment: a technology assessment. (EPA 832R-93-008), USEPA, Washington, DC.

Steiner, G.R., Combs, D.W., 1993. Small constructed wetlands systems for domestic wastewater treatment and their performance. In: Moshiri, G.A. (Ed.), Constructed wetlands for water quality improvement. Lewis Publishers, Boca Raton, FL, pp. 491-498.

Urbanc-Bercic, O., Bulc, T., 1995. Integrated constructed wetland for small communities. Water Sci. Technol. 32 (3), $41-47$.

USEPA, 1983. Methods for chemical analysis of water and wastes. (EPA 600/4-79-020) rev. March 83. USEPA, Washington, DC.

USEPA, 1998. National water quality inventory: 1998 report to congress. EPA 305(b) report, USEPA, Washington, DC.

USEPA, 1999. Constructed wetlands treatment of municipal wastewaters. (EPA 625-R-99-010). USEPA, Washington, DC.

Watson, J.T., Choate, K.D., Steiner, G.R., 1990. Performance of constructed wetland treatment systems at Benton, Hardin, and Pembrook, Kentucky during the early vegetation establishment phase. In: Cooper, P.F., Findlater, B.C. (Eds.), Constructed Wetlands in Water Pollution: Advances in Water Pollution Control. Pergamon Press, Great Britain, pp. 171-182.

Wittgren, H.B., Maehlum, T., 1997. Wastewater treatment wetlands in cold climates. Water Sci. Technol. 35 (5), $45-53$

Wood, A., 1995. Constructed wetlands in water pollution control: fundamentals to their understanding. Water Sci. Technol. 32 (3), 21-29. 